\title{
Using the ICF-CY to Support Inclusive Education in Ghana
}

\author{
Christiana Okyere, Catherine Donnelly, \\ and Heather Michelle Aldersey \\ Queen's University
}

\begin{abstract}
The international classification of functioning, disability, and health for children and youth (ICF-CY) developed by the World Health Organization (WHO) is a framework for understanding concepts of disability specific to children and youth. This framework has been used in countries around the world to support the education of children with disabilities. In this article, we argue that the ICF-CY has the potential to inform and support Ghana's education system and to improve the implementation of education for children with disabilities, particularly inclusive education, in Ghana. Specifically, we use children with intellectual and developmental disabilities (IDD) as an exemplar to examine how the ICF-CY can support inclusive education for children with disabilities within its main components: Body Functions and Structures, Activities and Participation, Environmental Factors, and Personal Factors. Examining the ICF-CY in these areas is significant, as many similar low- and middle-income contexts have yet to adopt the framework and may draw insights and lessons for its significance in educational contexts.
\end{abstract}

On July 31st, 2012, the Republic of Ghana ratified the United Nations Convention on the Rights of Persons with Disability. This convention emphasized equal educational opportunities for all persons with disabilities (United Nations, 2006). In addition to this important international policy commitment, Ghana also has national policies that confirm state responsibility for education for all. For example, in its Education Strategic Plan (2003-2015), the Republic of Ghana committed to including all children with mild to moderate disabilities in general education settings by 2015 (Republic of Ghana, 2003). However, critics have argued that existing policies for the right to education for children 
with disabilities have not yet resulted in equal educational opportunities for children with disabilities in practice (Agbenyega, 2006, 2007; Lamptey, Villeneuve, Minnes, \& McColl, 2015). For example, Lamptey et al.'s (2015) appraisal of Ghana's policy on inclusive education identified that the policy did not provide adequate resources, special materials, and supportive infrastructure to enable children with disabilities to benefit from general education settings. Further, the authors found public documents either to have not defined disability or to have defined disability in alignment with the medical model that perceives disability as problem inherent within an individual-and one to be fixed by medical treatment or interventions. The medical model does not recognize the influence and effects of social, environmental, and cultural factors on disability (Avoke, 2001; Oliver \& Barnes, 2012). Taking such a narrow perspective on disability can limit a child's opportunity to access environments that are physically, socially, and attitudinally conducive for appropriate education. Currently, the prevalence of the medical model in understanding disability in Ghana further isolates children with disabilities from inclusive to special segregated schools by its view of disability as a biological problem of the individual. The time, therefore, seems ripe for the exploration of concrete strategies for increasing translation of policy to practice.

The International Classification of Functioning, Disability, and Health (ICF) with its version for children and youth (ICF-CY) developed by the World Health Organization (WHO), is a universal framework for understanding concepts of health, functioning, and disability specific to children and youth. In contrast to the medical model, the ICF-CY views disability from a biopsychosocial perspective (World Health Organization, 2007), providing a holistic framework that examines functioning and environment in childhood and seeks to identify the needs of persons with disabilities (Hellblom-Thibblin, Klang, \& Åman, 2012). Thus, unlike the medical model, the ICF-CY framework recognizes the effects of biological, psychological, environmental, and social functioning on disability (Dahl, 2002; World Health Organization, 2001). In this article, we argue that the ICF-CY has the potential to inform and support Ghana's education system and to improve the implementation of inclusive education for children with disabilities. Specifically, we use children with intellectual and developmental disabilities (IDD) as an exemplar to examine how the ICF-CY framework can advance inclusive education for children with disabilities within its main components: Body Functions and Structures, Activities and Participation, Environmental Factors, and Personal Factors.

\section{Background}

The concept of inclusive education has been internationally accepted as a strategy for providing equal educational opportunities for children and youth with and without disabilities (World Health Organization \& World Bank, 2011). The literature identifies access, equity, and support as the core features of inclusive education (Ainscow, Booth, \& Dyson, 2016; Booth \& Ainscow, 2002; Hutchinson \& Martin, 2012; Jongbloed \& McColl, 2006). The extent to which environmental barriers to educational opportunities are addressed to promote the inclusion of students with disabilities in inclusive schools is termed access (Ainscow, 2000; Ainscow, Farrell, \& Tweddle, 2000; Chowdhury, 2011). Equity is fair treatment and equal opportunities for all students regardless of their disability status. Support refers to the availability of resources and services for students 
with disabilities to fully benefit from inclusive education opportunities in their respective communities (Villeneuve et al., 2013). Although governments are increasingly supporting inclusive education practice (i.e., access, equity, and support), there remains a lack of consensus about best approaches for moving policy and practice in a more inclusive direction (Ainscow \& Sandill, 2010). Many countries across the globe encounter challenges in implementing inclusive education; however, the situation demands more attention in low- and middle-income countries such as Ghana, where disability often signifies a disqualification from education (Ainscow \& Sandill, 2010; Botts \& Owusu, 2013; Reindal, 2010). The Republic of Ghana reports that approximately 3\% of its population are living with some form of disability (Ghana Statistical Service, 2012). However, global estimates record $10-15 \%$ of disability prevalence (World Health Organization \& World Bank, 2011). The discrepancies in prevalence estimates can be attributed to the perception and conceptualization of disability by researchers in various contexts. For example, in developing contexts in which persons with disabilities are often segregated, researchers often only include persons with visible disabilities in surveys (Yeo \& Moore, 2003). In a recent review on the status of inclusive education systems in Ghana, Ametepee and Anastasiou (2015) found that only 3\% of children with disabilities receive a basic primary education. The implementation of an inclusive education system in Ghana has been less effective due to diverse challenges including absence of modification of school curriculum, negative teacher attitudes and beliefs, lack of effective teacher training, and the absence of clear educational policies that are inclusive (Ametepee \& Anastasiou, 2015; Avoke, 2001; Bawa \& Mangope, 2011; Kuyini \& Desai, 2007).

\section{Critical Reflections on Educational Policies in Ghana}

The Republic of Ghana's commitment toward achieving education-related goals is reflected in several policy frameworks and legislation, including its 1992 Constitutions' Free Compulsory Universal Basic Education policy of 1996; Children's Act (Act 560) of 1998 (Republic of Ghana, 1998, 2003); Persons with Disability Act (Republic of Ghana, 2006); and Education Strategic Plan (ESP) of 2003-2015 and 2010-2020 (Republic of Ghana, 2003, 2012). Table 1 summarizes the contents of the main guiding policy documents relating to the education of children with disabilities in Ghana.

The ESPs of 2003-2015 and 2010-2020 have declared inclusive education as the most appropriate educational provision for students with disabilities. These policies sought to include all students with mild to moderate disabilities in inclusive education systems by 2015 (Republic of Ghana, 2003, 2012). In particular, the ESP of 2003-2015 sought (a) an increase in attendance for students with disabilities in schools to $50 \%$ in $2008,80 \%$ in 2012 , and $100 \%$ by 2015 ; and (b) the achievement of an inclusive education system for students with mild to moderate disabilities by 2015 (Ametepee \& Anastasiou, 2015). It is not clear, however, who constitutes children with non-severe and severe disabilities as the definition of disability; and criteria for determining levels of disability are not explicit in policy documents (Lamptey et al., 2015; Republic of Ghana, 2003, 2010). Also, it is interesting to note that a definition of inclusive education is not provided in the ESP of 2003-2015 or 2010-2020, making it difficult to compare Ghanaian definitions with global definitions of inclusive education. 
Table 1.

National Policies Pertaining to Education and Disability in Ghana

\begin{tabular}{|c|c|c|c|}
\hline Year & Policy Document & Educational Goal & Summary Contents \\
\hline 1992/1996 & $\begin{array}{l}\text { Republic of Ghana } 1992 \\
\text { Constitution-Free } \\
\text { Compulsory Universal } \\
\text { Basic Education of } 1996\end{array}$ & $\begin{array}{l}\text { Achieve free compulsory } \\
\text { universal primary or basic } \\
\text { education for all by } 2005 \\
\text { (Article 38) }\end{array}$ & $\begin{array}{l}\text { Details government targets and } \\
\text { strategies to achieve free } \\
\text { compulsory and quality education } \\
\text { for all }\end{array}$ \\
\hline 1998 & Children's Act (Act 560) & $\begin{array}{l}\text { Enforce the educational } \\
\text { rights and social- well- } \\
\text { being of all children } \\
\text { (section 10[2]) }\end{array}$ & $\begin{array}{l}\text { Details the rights of the child } \\
\text { including education, } \\
\text { maintenance and adoption, } \\
\text { regulation of child labour, and all } \\
\text { general matters relating to } \\
\text { children }\end{array}$ \\
\hline 2006 & Disability Act (715) & $\begin{array}{l}\text { Mandate the enrolment of } \\
\text { all children in school } \\
\text { (section 16-18) }\end{array}$ & $\begin{array}{l}\text { Details the rights of persons with } \\
\text { disabilities relating to education, } \\
\text { employment, health care services, } \\
\text { family life, and other related } \\
\text { matters }\end{array}$ \\
\hline $\begin{array}{l}2003-2015 \\
\text { and } \\
2010-2020\end{array}$ & $\begin{array}{l}\text { Education Strategic Plan } \\
\text { (ESP) }\end{array}$ & $\begin{array}{l}\text { Achieve inclusive } \\
\text { education for all children } \\
\text { with non-severe } \\
\text { disabilities by } 2015\end{array}$ & $\begin{array}{l}\text { Education sector policies, targets } \\
\text { and government strategies for the } \\
\text { plan period [2003-2015] and } \\
\text { [2010-2020] and targeted } \\
\text { outcomes }\end{array}$ \\
\hline
\end{tabular}

Although it does not provide a concrete definition, in each ESP the government associates inclusive education with integrating students with mild to moderate disabilities into mainstream schools (Republic of Ghana, 2003), enabling us to hypothesize that Ghana holds a definition of inclusive education that is in alignment with common ideals about the practice. Although the ideals and intentions associated with inclusion is access, equity, and support (Booth \& Ainscow, 2002; Hutchinson \& Martin, 2012; Jongbloed \& McColl, 2006), placement is the most frequent focus in practice. In particular, adaptations in teaching strategies, curriculum, and learning processes are often a lower priority in inclusive education (Haug, 2017). We believe that given (a) its roots in the biopsychosocial approach to understanding disability (World Health Organization, 2007) and (b) its use to guide disability policies around the world (Campbell \& Skarakis-Doyle, 2007; Cieza et al., 2004; Sanches-Ferreira et al., 2013), the ICF-CY framework may be a crucial, concrete tool that could be used by policy makers and practitioners to make a shift from policy on paper to policy in action in Ghana.

\section{Understanding the Influence of the ICF-CY Framework on Inclusive Education}

The ICF-CY was derived from the ICF to understand concepts of disability specific to developing children and youth that could be universally used by them in health, education, and the social sector (World Health Organization, 2007). The ICF-CY framework comprises two main parts, Functioning and Disability (Part 1) and Contextual Factors (Part 2), each of which has two components (WHO, 2002, pp. 9-10). Part 1 consists of Body Functions and Structures and Activities and Participation (i.e., tasks and 
activities). Part 2 comprises Environmental Factors (e.g., policies and legislation, societal attitudes) and Personal Factors (e.g., age, gender, intellectual level). Each component of the ICF-CY framework has various corresponding domains and categories.

The ICF-CY framework has been widely applied across multiple sectors, including health, education, and disability public policy (Cieza et al., 2004). Professionals have employed the framework to understand disability and have further developed brief core sets for specific health conditions (Cieza et al., 2004; Steiner et al., 2002). The ICF has also been used as an educational problem-solving tool to guide eligibility policy and practice in special education (Campbell \& Skarakis-Doyle, 2007; Hellblom-Thibblin et al., 2012; Sanches-Ferreira et al., 2013). For example, the government of Portugal employed it to assess type and severity of disability required for children to benefit from special education services (Sanches-Ferreira et al., 2013). Similarly, the Swiss government used the framework to establish the eligibility of children with disabilities in special schools (Hollenweger, 2011). We believe that the ICF-CY framework could serve as a concrete tool for advancing inclusive education for children with IDD in Ghana and similar contexts. Using its four main components, the following section identifies how the ICF-CY framework could support key stakeholders in advancing inclusive education for children with IDD in Ghana.

\section{Body Functions and Structures}

The World Health Organization's International Classification of Diseases Working Group defines IDD as "a group of developmental conditions characterized by significant impairment of cognitive functions, which are associated with limitations of learning, adaptive behaviour and skills" (Salvador-Carulla et al., 2011, p. 177). Generally, persons with IDD experience difficulties in perceptual reasoning, verbal comprehension, processing speed, and working memory due to cognitive impairment (Salvador-Carulla et al., 2011). Generally, children with IDD receive education in special segregated schools, which excludes them from mainstream societies and from inclusive educational opportunities (Avoke, 2001; Gyimah, 2001; Lamptey et al., 2015). Research in low- and middle-income contexts shows that children with IDD who receive education in inclusive schools experience challenges in maintaining motivation in the learning process (Engelbrecht, Nel, Smit, \& Deventer, 2016; Okyere, Aldersey, \& Lysaght, in press; Westbrook \& Croft, 2015). For example, in a study that explored the experiences of children with IDD in inclusive schools in Ghana, Okyere et al. (in press) found that unlike their peers without disabilities, children with IDD exhibit problem behaviours and experience difficulties in learning and applying practical knowledge in the general education classroom.

The domains for Body Functions and Structures most related to the child with IDD are: (b1) Mental Functions (e.g., b117, intellectual functions; b126, temperament and personality functions); (b3) Voice and Speech Functions; and (s1) Structures of the Nervous System. The domains for Body Functions and Structures are a significant reference guide to the assessment of functioning profiles, identification of specific needs, and development of systematic intervention plans (Selb et al., 2015; World Health Organization, 2007). We believe that introducing the ICF-CY framework into educational 
systems in Ghana may help teachers to better understand functioning or deficits in mental functions and brain structure that affect problem behaviours and learning challenges as it relates to the child with IDD. Subsequently, the framework can guide the development of specialized assessments and adaptations or modifications in instructional strategies and curriculum, ultimately leading to increased participation and inclusion of the child with IDD. In a study that explored professionals' perception of the ICF-CY in Sweden, Adolfsson, Granlund, Björck-Akesson, Ibragimova, and Pless (2010) found that introducing the ICF-CY framework in school systems increased teachers' understanding about students' individual needs, which also supported the establishment and evaluation of individualized support. Similarly, in an investigation of the feasibility of applying the ICF-CY in school settings in De Polo, Pradal, Bortolot, Buffoni, \& Martinuzzi (2009) found that the ICF-CY aided educational teams' and professionals' understanding of students' individual needs, which also aided their understanding of the most suitable environments for satisfying their students' specific needs. It is noteworthy that these best practices come from developed countries with a history of using the ICF-CY to understand and support the inclusion of children with disabilities including those with IDD. This demonstrates a need for an exploration of the ICF-CY framework with children with IDD in inclusive education settings in Ghana.

\section{Activity and Participation}

The domains for Activity and Participation include a range of life areas, from learning and applying knowledge to areas such as interpersonal interactions and relationships, and community, social, and civic life (World Heath Organization, 2007). In educational settings, the Activity and Participation component describes the ability or difficulties a child may encounter in executing school tasks, activities, and daily routines typical of their respective age (World Heath Organization, 2007). This component lists nine domains, four of which are particularly applicable to children with IDD: (d1) learning and applying knowledge, (d2) general tasks and demands, (d3) communication, (d5) self-care, and (d7) interpersonal interactions and relationships. Research shows that children with IDD often experience significant activity limitations and participation restrictions in learning to read and write, completing exercises, and joining in play activities and conversations with peers in inclusive schools (Dalton, Mckenzie, \& Mckenzie, 2012; Franck \& Joshi, 2017; Mapuranga, Dumba, \& Musodza, 2015).

Generally, teachers encounter diverse challenges supporting children with IDD, including navigating strategies to support their social participation and relationship building (Leeuw, de Boer, Bijstra \& Minnaert, 2018; Okyere, Aldersey \& Lysaght, in press). The literature identifies four key features of social participation: friendship, interaction, social self-perception, and acceptance by peers (Koster, Nakken, Pijl, \& van Houten, 2009). Children with IDD can achieve social participation in the general education classroom through positive interactions with friends and classmates, which leads to an overall sense of belonging (de Leeuw et al., 2018; Koster et al. 2009). The significance of the ICF-CY lies in its role as an important guide to how teachers might remove physical barriers to accommodate potential impacts of impairments and activity limitations and to encourage opportunities for interactions and co-operation 
between children with and without IDD (World Health Organization, 2013). Accommodating potential impacts of activity limitations can take the form of (a) individualized outcomes that match functioning profiles, (b) suitable physical environments and modified classroom activities that support social participation and relationship building, and (c) policies that make provisions for the realization of these accommodations.

\section{Contextual Factors}

Contextual Factors "represent the complete background of an individual's life and living" (World Heath Organization, 2007, p. 15). It comprises two componentsEnvironmental Factors and Personal Factors - that either act as facilitators or barriers to an individual's functioning (World Heath Organization, 2007). Considerations of the specific needs of children with disabilities in inclusive education contexts can be identified and met if all relevant Contextual Factors are addressed to promote their inclusion (Hollenweger, 2011). Teachers' understanding of the influence of Contextual Factors on the child with IDD could serve as a useful guide to the creation of learning environments that improve their capacity and performance (De Polo et al., 2009). As Taylor (2004) noted, "Services for students with disabilities should come with a presumption in favour of environments that are least restrictive and most normalized, independent, and integrated" (p. 219).

Environmental Factors. The functioning of the individual in this component is documented into five domains: (e1) products and technology; (e2) natural environment and human-made changes to environment; (e3) support and relationships; (e4) attitudes; and (e5) services, systems, and policies. The application of the ICF-CY could influence the development and monitoring of clear educational policies related to equitable access that would promote inclusive education environments, given its holistic approach to disability and participation (Maxwell \& Koutsogeorgou, 2012). Within Ghana's inclusive education system, the ICF-CY could shape educational policies and legislation to support children with disabilities by broadening the lens of how disability is viewed and defined. With the current medical lens, the influence of cultural factors (beliefs and practices) on disability is not recognized in policy and legislation (Oliver \& Barnes, 2012). From the educational perspective in Ghana, a solely individual-deficitbased model for understanding disability translates to a number of concerns: (a) negative teacher attitudes toward children with IDD, (b) isolation of children with IDD into special segregated schools and thus less access to integration and, (c) feelings of underachievement on the part of children with IDD (Adjei, 2006; Agbenyega, 2007; Kuyini \& Desai, 2007). Introducing strategies for identification and classification of students based on the ICF-CY into Ghana's educational contexts might have a reciprocal influence on policies, causing policy makers to consider contextual effects on the educational attainment of the child with IDD. Specifically, the ICF-CY framework could influence special education policies to clearly embed the core features of inclusive education - access, equity and support - that would further support their integration into schools and communities. 
Personal Factors. These factors are the "features of the individual that are not part of the health condition" (World Health Organization, 2007, p. 15). These include age, gender, motivation and intellectual level, and coping styles. It is noteworthy that despite its influence on functioning and on intervention outcomes, Personal Factors are not classified on the current version of the ICF-CY framework due to disparities in societies and cultures around the globe (Westby \& Washington, 2017; World Health Organization, 2007). Compared to their typically developing peers, children with IDD are more likely to exhibit destructive behaviours, negative dispositions, and poorer self-regulation and temper tantrums (Lakhan \& Kishore, 2018). An identification and in-depth understanding of Personal Factors such as motivation, intellectual capacity, and temperament of the child with IDD can guide the development of the most suitable instructional strategies that support their functioning and, ultimately, inclusion (Sanches-Ferreira et al., 2013). Instructional strategies may take forms such as individualized education plans (IEPs), modifications and adaptation of curriculum, and instructional practices (Dee, 2010; Gal, Schreur, \& Engel-Yeger, 2010). For example, teachers can use multiple-sensoryapproach flexible teaching methods (i.e., visual and auditory instructions), offer regular feedback, break tasks into small learning chunks, or create an accessible classroom to ensure that children with IDD benefit in inclusive schools.

Some basic and junior high schools in Ghana encourage the adoption of pedagogical strategies that are considerate of Personal Factors, inclusive, and child-centred (Ampiah, 2008). However, recent studies have shown few or no adaptations in instructional strategies and curriculum to accommodate the factors unique to each child with a disability in the general education settings (Eller, Fisher, Gilchrist, Rozman, \& Shockney, 2016; Singal, Salifu, Iddrisu, Casely-Hayford, \& Lundebye, 2015). Factors such as inadequate resources, overcrowded classrooms, and lack of teacher training and preparation have led to the absence of the development of individualized support based on the personal factors and unique needs of the child with IDD (Avoke, 2001; Bawa \& Mangope, 2011). The development of individualized support such as IEPs has thus been inconsistent and limited in scope, due to educational materials and programs or instructional methods that are inappropriately matched to the unique Personal Factors of each child (Avoke, 2001; Okyere \& Adams, 2003). The application of the ICF-CY in Ghana's education system may serve as the first concrete and applicable step that stakeholders (e.g., Ghana Education Systems, Special Education Division, and teachers) can take, to support the development of individualized support that is consistent, comprehensive, and in alignment with the specific Personal Factors of the child with IDD. By considering the Personal Factors of each child with IDD, teachers can better understand the characteristics of the child that affect their behaviours, capacity, and performance and can adapt resources and services to ensure their full participation and inclusion (Washington, 2007). 
Table 2.

Application of the ICF-CY Framework in Inclusive Education

\begin{tabular}{|c|c|c|c|}
\hline Components ${ }^{1}$ & Applicable Domains ${ }^{2}$ & $\begin{array}{l}\text { Application to the Child with } \\
\text { IDD }\end{array}$ & $\begin{array}{l}\text { Integrating the ICF-CY into Inclusive } \\
\text { Education }\end{array}$ \\
\hline $\begin{array}{l}\text { Body Functions and Structures } \\
\text { Physiological or psychological functions } \\
\text { of body systems and anatomical parts of } \\
\text { the body (i.e. organs and limbs) }\end{array}$ & $\begin{array}{l}\text { (b1) Mental Functions } \\
\text { (b3) Voice and Speech } \\
\text { Functions } \\
\text { (s1) Structures of the } \\
\text { Nervous System }\end{array}$ & $\begin{array}{l}\text { Impairments in intellectual } \\
\text { functioning (e.g. memory } \\
\text { functions) and in adaptive } \\
\text { behaviour }\end{array}$ & $\begin{array}{l}\text { - Provides a framework for a better } \\
\text { understanding the child with IDD's needs } \\
\text { - Can serve as the basis for determining } \\
\text { the eligibility of the child with IDD for } \\
\text { inclusive education } \\
\text { - Can identify educational needs and } \\
\text { goals of the child with IDD }\end{array}$ \\
\hline $\begin{array}{l}\text { Activity and Participation } \\
\text { Activity: Execution of a task by the } \\
\text { individual } \\
\text { Activity limitation: Challenges an indivi- } \\
\text { dual may encounter executing a task. } \\
\text { Participation: An individual's involvement } \\
\text { in a life situation. } \\
\text { Participation restriction: Problems an } \\
\text { individual may encounter while involved } \\
\text { in a life situation }\end{array}$ & $\begin{array}{l}\text { (d1) Learning and } \\
\text { Applying Knowledge } \\
\text { (d2) General Tasks and } \\
\text { Demands } \\
\text { (d3) Communication } \\
\text { (d5) Self-care } \\
\text { (d7) Interpersonal } \\
\text { Interactions and } \\
\text { Relationships }\end{array}$ & $\begin{array}{l}\text { Limitations in activities (e.g. } \\
\text { difficulties in learning, reading, } \\
\text { writing completing class } \\
\text { exercises) } \\
\text { Participation restrictions (e.g. } \\
\text { decreased involvement in } \\
\text { classroom and recreational } \\
\text { activities. Decreased } \\
\text { involvement in conversations } \\
\text { with peers and play activities }\end{array}$ & $\begin{array}{l}\text { - Provides a framework for } \\
\text { accommodating individual needs: } \\
\text { - Identifying appropriate individual } \\
\text { instructional strategies } \\
\text { - Modifying curriculum and } \\
\text { classroom/school activities and } \\
\text { assessments } \\
\text { - Facilitates full participation and inclusion } \\
\text { of the child with IDD }\end{array}$ \\
\hline $\begin{array}{l}\text { Contextual Factors } \\
\text { Environmental factors: The physical, social } \\
\text { and attitudinal environment (e.g. family, } \\
\text { school) surrounding an individual life. } \\
\text { Personal factors: The characteristics (e.g. } \\
\text { sex, age, gender, health conditions) that } \\
\text { makes each individual unique. }\end{array}$ & $\begin{array}{l}\text { (e2) Natural Environment } \\
\text { and Human-Made } \\
\text { Changes to the } \\
\text { Environment } \\
\text { (e3) Support and } \\
\text { Relationships } \\
\text { (e5) Attitudes, Services, } \\
\text { Systems and } \\
\text { Policies }\end{array}$ & $\begin{array}{l}\text { Environmental Factors (e.g. } \\
\text { special education } \\
\text { policies/legislation that do not } \\
\text { make provision for appropriate } \\
\text { resources and services). } \\
\text { Personal Factors (e.g. level of } \\
\text { intellectual capacity and } \\
\text { motivation) }\end{array}$ & $\begin{array}{l}\text { - Provides insights into environmental and } \\
\text { personal factors that facilitate or impede } \\
\text { the functioning of the child with IDD } \\
\text { within an inclusive settings } \\
\text { - Provides a framework for assessing and } \\
\text { adapting contextual factors to } \\
\text { accommodate the inclusion of the child } \\
\text { with IDD }\end{array}$ \\
\hline
\end{tabular}

Notes: ${ }^{1}$ WHO (2001), p. $10 .{ }^{2}$ WHO (2007) pp. 31-42. 


\section{Potential Challenges of the ICF-CY}

While the ICF-CY has been beneficial in assessing the health of children and youth and for analyzing educational processes and systems (Adolfsson et al., 2010; De Polo et al., 2009; Hellblom-Thibblin et al., 2012; Maxwell \& Koutsogeorgou, 2012), some concerns have been raised in the literature regarding its application in educational contexts. First, the use of the ICF-CY in establishing the eligibility of children with disabilities to benefit from special education services may form the basis for further segregation and discrimination rather than support and equalization of opportunities (Hollenweger, 2013). While a significant concern, it is important to note that the purpose of the ICF-CY is not to categorize people, but rather the impairments and participation restrictions they experience, and to identify the environmental factors that affect their experiences (Simeonsson et al., 2006). Therefore, we believe that countries could employ the ICF-CY to define and support the unique needs of children with disabilities in inclusive education systems rather than categorize them in a way that might compromise equalization of opportunities. This way, the ICF-CY's purpose of a non-discriminatory approach to disability would be promoted (Simeonsson et al., 2006). Second, some education professionals have rated the ICF-CY as complex due to their difficulty in understanding its concepts (Sanches-Ferreira, Silveira-Maia, \& Alves, 2014). Again, while an important concern, it is noteworthy that the ICF-CY has been instrumental in promoting collaborative service delivery among clinicians and education professionals as it relates to addressing the individual needs of students with disabilities in school settings (Campbell \& Skarakis-Doyle, 2007). We believe that the ICF-CY also provides a framework for collaborative partnerships through which educational professionals can receive the support they require to understand core concepts.

In developing contexts such as Ghana, the contribution of rehabilitation professionals to persons with disabilities has often been limited to therapeutic services such as occupational therapy, physical therapy and speech and language therapy outside educational settings (Kumar, Roy, \& Kar, 2012; Sayers, 2008; Teerink, 1999; Tinney, Chiodo, Haig, \& Wiredu, 2007). The Department of Social Welfare and Department of Health in Ghana are required to assist in assessing children's educational needs. However, there is little or no collaboration among these departments and education professionals in Ghana (Gyimah, Sugden, \& Pearson, 2009). The common language for communication that the ICF-CY offers could contribute to the development of strong collaborations among health and educational professionals, which also supports educational professionals' understanding of core concepts (World Health Organization, 2007).

Further, in terms of resources, efforts, and time, De Polo et al. (2009) described the process of using the ICF-CY "as neither simple nor easy" (p. 73). We believe that the complexities surrounding the applicability of the ICF-CY in educational contexts can be mitigated by an investment into specialized training of educational professionals on all key elements and concepts of the ICF-CY (Sanches-Ferreira et al., 2014). To that end, despite the outlined limitations of ICF-CY use, we believe that the positive aspects of its application outweigh the potential negative impacts, particularly when intentional steps are made to safeguard against the limitations. Although the potential cautions against the 
ICF-CY are valid and must be taken into consideration, we believe that the potential positives for closing the gap between policy and practice outweigh the potential negatives.

\section{Conclusion and Future Directions}

Given the standing international requirement for inclusive approaches for all children with disabilities, the ICF-CY framework can play an important role in supporting inclusive education. The challenges that children with IDD in Ghana face can be attributed to environmental factors, i.e., education policies and legislation that are embedded within the medical model, and a society that discriminates against all children with disabilities. The ICF-CY offers a framework for inclusion without compromising core educational principles. Using a biopsychosocial approach to disability, it offers a holistic basis for assessing children and developing appropriate, individualized supports for full participation and inclusion. The ICF-CY can also support teachers in developing and implementing teaching strategies to support children and can offer a common language for collaborating among disciplines. The use of the ICF-CY in Ghana's education system can thus promote effective inclusive education implementation by guiding policy makers and professionals to identify and document characteristics relevant to improving the functioning and participation of children with disabilities in inclusive classrooms. Examining the applicability of the ICF-CY in educational contexts is relevant to its adoption in Ghana and similar low- and middle-income contexts. This paper was the first in this process.

\section{References}

Adjei, F. A. (2006). A preliminary study of teachers' perception on inclusive education. Journal of Special Education Needs, 4(3), 351-361.

Adolfsson, M., Granlund, M., Björck-Akesson, E., Ibragimova, N., \& Pless, M. (2010). Exploring changes over time in habilitation professionals' perceptions and applications of the international classification of functioning, disability and health, version for children and youth (ICF-CY). Journal of Rehabilitation Medicine, 42(7), 670-678. doi:10.2340/16501977-0586

Agbenyega, J. (2006). Corporal punishment in the schools of Ghana: Does inclusive education suffer? Austrailian Educational Researcher, 33(3), 107-122. doi:10.1007/BF03216844

Agbenyega, J. (2007). Examining teachers' concerns and attitudes to inclusive education in Ghana. International Journal of Wholeschooling, 3(1), 41-56.

Ainscow, M. (2000). Reaching out to all learners: Some lessons from international experience. School Effectiveness and School Improvement, 11(1), 1-19. doi:10.1076/0924-3453(200003)11:1;1\#;FT001

Ainscow, M., Booth, T., \& Dyson, A. (2016). Inclusion and the standards agenda: Negotiating policy pressures in England. International Journal of Inclusive Education, 10(4), 295-308.

Ainscow, M., Farrell, P., \& Tweddle, D. (2000). Developing policies for inclusive education: A study of the role of local education authorities. International Journal of Inclusive Education, 4(3), 211-229.

Ainscow, M., \& Sandill, A. (2010). Developing inclusive education systems: The role of organisational cultures and leadership. International Journal of Inclusive Education, 14(4), 401-416. 
Ametepee, L. K., \& Anastasiou, D. (2015). Special and inclusive education in Ghana: Status and progress, challenges and implications. International Journal of Educational Development, 41, 143-152. doi:10.1016/j.ijedudev.2015.02.007

Ampiah, J. G. (2008). An investigation of provision of quality basic education in Ghana: A case study of selected schools in the Central Region. Journal of International Cooperation in Education, 11(3), 19-37.

Asante, L. A., \& Sasu, A. (2015). The persons with disability Act , 2006 ( Act 715 ) of the Republic of Ghana: The law, omissions and recommendations. Journal of Law, Policy and Globalization, 36, 62-68.

Avoke, M. (2001). Some historical perspectives in the development of special education in Ghana. European Journal of Special Needs Education, 16(1), 29-40. doi:10.1080/08856250150501789

Bawa, A. K., \& Mangope, B. (2011). Student teachers' attitudes and concerns about inclusive education in Ghana and Botswana. International Journal of Whole Schooling, 7(1), 20-37.

Booth, T., \& Ainscow, M. (2002). Index for inclusion developing learning and participation in schools. Bristol, UK: Centre for Studies on Inclusive Education. Retrieved February 7, 2016, from http://www.eenet.org.uk/resources/docs/Index English.pdf

Botts, B. H., \& Owusu, N. A. (2013). The state of inclusive education in Ghana, West Africa. Preventing School Failure: Alternative Education for Children and Youth, 57(3), 135-143. doi:10.1080/1045988X.2013.798776

Campbell, W. N., \& Skarakis-Doyle, E. (2007). School-aged children with SLI: The ICF as a framework for collaborative service delivery. Journal of Communication Disorders, $40(6), 513-535$.

Chowdhury, P. R. (2011). The right to inclusive education of persons with disabilities: The policy and practice implications. Asia-Pacific Journal on Human Rights and the Law, 12(2), 1-35. doi:10.1163/138819011X13215419937869

Cieza, A., Ewert, T., Berdirhan Üstün, T., Chatterji, S., Kostanjsek, N., \& Stucki, G. (2004). Development of ICF Core Sets for patients with chronic conditions. Journal of Rehabilitation Medicine, 36(SUPPL. 44), 9-11. doi:10.1080/16501960410015353

Dahl, T. H. (2002). International classification of functioning, disability and health: An introduction and discussion of its potential impact on rehabilitation services and research. Journal of Rehabilitation Medicine, 34(5), 201-204. doi:10.1080/165019702760279170

Dalton, E. M., Mckenzie, J. A., \& Mckenzie, J. (2012). The implementation of inclusive education in South Africa: Reflections arising from a workshop for teachers and therapists to introduce universal design for learning inclusive education in South Africa. African Journal of Disability, 1(1), 1-7. doi:10.4102/ajod.v1i1.13

de Leeuw, R. R., de Boer, A. A., Bijstra, J., \& Minnaert, A. E. M. G. (2018). Teacher strategies to support the social participation of students with SEBD in the regular classroom. European Journal of Special Needs Education, 33(3), 412-426. doi:10.1080/08856257.2017.1334433

De Polo, G., Pradal, M., Bortolot, S., Buffoni, M., \& Martinuzzi, A. (2009). Children with disability at school: The application of ICF-CY in the veneto region. Disability and Rehabilitation, 31(1), S67-S73. doi:10.3109/09638280903317880

Dee, A. L. (2010). Preservice teacher application of differentiated instruction. The Teacher Educator, 46(1), 53-70. doi:10.1080/08878730.2010.529987

Eller, M., Fisher, E., Gilchrist, A., Rozman, A., \& Shockney, S. (2016). Is inclusion the only option for students with learning disabilities and emotional behavioral disorders? The Undergraduate Journal of Law \& Disorder, 5, 79-86. 
Engelbrecht, P., Nel, M., Smit, S., \& Deventer, M. Van. (2016). The idealism of education policies and the realities in schools: The implementation of inclusive education in South Africa. International Journal of Inclusive Education, 20(5), 520-535. doi:1080/13603116.2015.1095250

Franck, B., \& Joshi, D. K. (2017). Including students with disabilities in Education for All: Lessons from Ethiopia. International Journal of Inclusive Education, 21(4), 347-360. doi:10.1080/13603116.2016.1197320

Gal, E., Schreur, N., \& Engel-Yeger, B. (2010). Inclusion of children with disabilities: Teachers attitudes and requirements for environmental accommodations. International Journal of Special Education, 25(2), 89-99.

Ghana Statistical Service. (2012). 2010 population \& housing census: Summary report of final results. Accra, Ghana: Author. Retrieved September 5, 2018, from http://www.statsghana.gov.gh /gssmain/storage/img/marqueeupdater/Census2010_Summary_report_of_final_results.pdf

Gyimah, E. K. (2001). Service to the mentally challenged: The case of twin-city special school for the mentally handicapped, Sekondi-Takoradi. IFE PsychologIA, 9(2), 127-134. doi:10.4314/ifep.v9i2.23622

Gyimah, E. K., Sugden, D., \& Pearson, S. (2009). Inclusion of children with special educational needs in mainstream schools in Ghana: Influence of teachers' and children's characteristics. International Journal of Inclusive Education, 13(8), 787-804.

Haug, P. (2017). Understanding inclusive education: Ideals and reality. Scandinavian Journal of Disability Research, 19(3), 206-217. doi:10.1080/15017419.2016.1224778

Hellblom-Thibblin, T., Klang, N., \& Åman, K. (2012). Biopsychosocial model and the ICF-CY in inservice training: General educators' reflections. British Journal of Developmental Disabilities, 58(1), 12-19. doi:10.1179/2047387711Y.0000000003

Hollenweger, J. (2011). Development of an ICF-based eligibility procedure for education in Switzerland. BMC Public Health, 11 (Suppl 4), S7-S7. doi:10.1186/1471-2458-11-S4-S7

Hollenweger, J. (2013). Developing applications of the ICF in education systems: Addressing issues of knowledge creation, management and transfer. Disability and Rehabilitation, 35(13), 1087-1091. doi:10.3109/09638288.2012.740135

Hutchinson, L. N., \& Martin, A. K. (2012). Inclusive classrooms in Ontario schools. Toronto, ON: Pearson Canada.

Jongbloed, L., \& McColl, M. A. (2006). Disability and social policy in Canada (2nd ed.). Concord, ON: Captus Press.

Koster, M., Nakken, H., Pijl, S. J., \& van Houten, E. (2009). Being part of the peer group: A literature study focusing on the social dimension of inclusion in education. International Journal of Inclusive Education, 13(2), 117-140. doi:10.1080/13603110701284680

Kumar, S. G., Roy, G., \& Kar, S. S. (2012). Disability and rehabilitation services in India: Issues and challenges. Journal of Family Medicine and Primary Care, 1(1), 69-73. doi:10.4103/22494863.94458

Kuyini, A. B., \& Desai, I. (2007). Principals' and teachers' attitudes and knowledge of inclusive education as predictors of effective teaching practices in Ghana. Journal of Research in Special Educational Needs, 7(2), 104-113. doi:10.1111/j.1471-3802.2007.00086.x

Lakhan, R., \& Kishore, M. T. (2018). Behaviour problems in children with intellectual disabilities in a resource-poor setting in India-Part 1: Association with age, sex, severity of intellectual disabilities and IQ. Journal of Applied Research in Intellectual Disabilities, 31(1), 43-50. doi:10.1111/jar.12278 
Lamptey, D.-L., Villeneuve, M., Minnes, P., \& McColl, M. A. (2015). Republic of Ghana's policy on inclusive education and definitions of disability. Journal of Policy and Practice in Intellectual Disabilities, 12(2), 108-111. doi:10.1111/jppi.12114

Mapuranga, B., Dumba, O., \& Musodza, B. (2015). The impact of inclusive education (I.E.) on the rights of children with intellectual disabilities (IDs) in Chegutu. Journal of Education and Practice, 6(30), 214-223.

Maxwell, G., \& Koutsogeorgou, E. (2012). Using social capital to construct a conceptual International Classification of Functioning, Disability, and Health, Children and Youth Version-based framework for stronger inclusive education policies in Europe. American Journal of Physical Medicine \& Rehabilitation, 91(13, Suppl 1), S118-S123. doi:10.1097/PHM.0b013e31823d4b92

Okyere, B. A., \& Adams, J. S. (2003). Issues in educating exceptional children in Africa. In Introduction to special education: An African perspective (pp. 29-41). Accra, Ghana: Adwinsa Publications.

Okyere, C., Aldersey, H. M., \& Lysaght, R. (in press). The experiences of children with intellectual and developmental disabilities in inclusive schools in Accra, Ghana. African Journal of Disability.

Oliver, M., \& Barnes, C. (2012). The new politics of disablement (2nd ed.). New York, NY: Palgrave Macmillan.

Reindal, S. M. (2010). What is the purpose? Reflections on inclusion and special education from a capability perspective. European Journal of Special Needs Education, 25(1), 1-12. doi:10.1080/08856250903450806

Republic of Ghana. (1998). Children's Act (Act 560). Retrieved March 03, 2017, from http://www.unesco.org/education/edurights/media/docs/f7a7a002205e07fbf1 19bc00c8bd3208 a438b37f.pdf

Republic of Ghana. (2003). Education Strategic Plan (2003-2015). Retrieved August 8, 2017, from http://unescoghana.org/wp-content/uploads/2017/08/Ghana-EFA-NAP-Finalised-Version.pdf

Republic of Ghana. (2010). Education strategic plan 2010-2020, vol. 1. Policies, strategies, delivery, finance. Retrieved April 22, 2018, from https://www.globalpartnership.org/content /government-ghana-education-strategic-plan-2010-2020-volume-1-policies-strategiesdelivery

Republic of Ghana. (2012). Education strategic plan 2010-2020, vol. 2. Strategies and work program. Retrieved May 15, 2017, from https://www.globalpartnership.org/content/government-ghanaeducation-strategic-plan-2010-2020-volume-1-policies-strategies-delivery

Salvador-Carulla, L., Reed, G. ., Vaez-Azizi, L. M., Cooper, S.-A., Martinez-Leal, R., Bertelli, M., ... Saxena, S. (2011). Intellectual developmental disorders: Towards a new name, definition and framework for "mental retardation/intellectual disability" in ICD-11. World Psychiatry, $10(3), 175-180$.

Sanches-Ferreira, M., Silveira-Maia, M., \& Alves, S. (2014). The use of the International Classification of Functioning, Disability and Health, version for children and youth (ICF$\mathrm{CY}$ ), in Portuguese special education assessment and eligibility procedures: The professionals' perceptions. European Journal of Special Needs Education, 29(3), 327-343. doi:10.1080/08856257.2014.908025

Sanches-Ferreira, M., Simeonsson, R. J., Silveira-Maia, M., Alves, S., Tavares, A., \& Pinheiro, S. (2013). Portugal's special education law: Implementing the International Classification of Functioning, Disability and Health in policy and practice. Disability \& Rehabilitation, 35(10), 868-873. doi:10.3109/09638288.2012.708816 
Sayers, B. R. (2008). Collaboration in school settings: A critical appraisal of the topic. Journal of Occupational Therapy, Schools, \& Early Intervention, 1(2), 170-179. doi:10.1080/19411240802384318

Selb, M., Escorpizo, R., Kostanjsek, N., Stucki, G., Üstün, B., \& Cieza, A. (2015). A guide on how to develop an International Classification of Functioning, Disability and Health core set. European Journal of Physical and Rehabilitation Medicine, 51(1), 105-117.

Simeonsson, R. J., Leonardi, M., Bjorck-Akesson, E., Hollenweger, J., Lollar, D., Martinuzzi, A., \& TenNapel, H. (2006, October). ICF-CY: A universal tool for practice policy and research (Doc. WHOFIC2006-P107). A paper presented at the Meeting of WHO Collaborating Centres for the Family of International Classifications, Tunis, Tunisia.

Singal, N., Salifu, E. M., Iddrisu, K., Casely-Hayford, L. H., \& Lundebye, H. (2015). The impact of education in shaping lives: Reflections of young people with disabilities in Ghana. International Journal of Inclusive Education, 19(9), 908-925. doi:10.1080/13603116.2015.1018343

Steiner, W. A., Ryser, L., Huber, E., Uebelhart, D., Aeschlimann, A., \& Stucki, G. (2002). Use of the ICF model as a clinical problem-solving tool in physical therapy and rehabilitation medicine. Physical Therapy, 82(11), 1098-1107. doi:10.1093/ptj/82.11.1098

Taylor, S. J. (2004). Caught in the continuum: A critical analysis of the principle of the least restrictive environment. Research \& Practice for Persons with Severe Disabilities, 29(4), 218-230. doi:10.2511/rpsd.29.4.218

Teerink, M. T. (1999). A survey of rehabilitative services and people coping with physical disabilities in Uganda, East Africa. International Journal of Rehabilitation Research, 22(4), 311-316. doi:10.1097/00004356-199912000-00008

Tinney, M. J., Chiodo, A., Haig, A., \& Wiredu, E. (2007). Medical rehabilitation in Ghana. Disability and Rehabilitation, 29(11-12), 921-927. doi:10.1080/09638280701240482

United Nations. (2006). Convention on the rights of persons with disabilities and optional protocol. New York, NY: Author. Retrieved June 20, 2016, from http://www.un.org/disabilities /documents/convention/convoptprot-e.pdf

Villeneuve, M., Hutchinson, N. L., Minnes, P., Perry, A., Dionne, C., Isaacs, B., ... Weiss, J. (2013). The experience of parents as their children with developmental disabilities transition from early intervention to kindergarten. Canadian Journal of Education, 36(1), 4-43.

Washington, K. N. (2007). Using the ICF within speech-language pathology: Application to developmental language impairment. Advances in Speech Language Pathology, 9(3), 242255. doi:10.1080/14417040701261525

Westbrook, J., \& Croft, A. (2015). Beginning to teach inclusively: An analysis of newly qualified teacher pedagogy in lower primary classes in Tanzania. Teaching and Teacher Education, 51, 38-46. doi:10.1016/j.tate.2015.05.003

Westby, C., \& Washington, K. N. (2017). Using the International Classification of Functioning, Disability and Health in assessment and intervention of school-aged children with language impairments. Language Speech and Hearing Services in Schools, 48(3), 137-152. doi:10.1044/2017_LSHSS-16-0037

World Health Organization. (2001). International classification of functioning, disability and health. Geneva, Switzerland: Author. Retrieved July 1, 2016, from http://www.who.int /classifications/icf/icfbeginnersguide.pdf

World Health Organization. (2007). International classification of functioning, disability and health for children and youth (ICF-CY). Geneva, Switzerland: Author. Retrieved July 1, 2016, from http://apps.who.int/iris/bitstream/10665/43737/1/9789241547321_eng.pdf 
World Health Organization. (2013). How to use the ICF: A practical manual for using the International Classification of Functioning, Disability and Health (ICF). Exposure draft for comment. Geneva, Switzerland: Author. Retrieved August 2, 2016, from http://www.who.int /classifications/drafticfpracticalmanual.pdf

World Health Organization \& World Bank. (2011). World report on disability. Geneva, Switzerland: World Health Organization. Retrieved October 7, 2016, from http://www.who.int /disabilities/world_report/2011/report.pdf

Yeo, R., \& Moore, K. (2003). Including disabled people in poverty reduction work: "Nothing about us, without us." World Development, 31(3), 571-590. doi:10.1016/S0305-750X(02)00218-8

\section{Authors' Note}

Correspondence concerning this article should be addressed to Christiana Okyere, School of Rehabilitation Therapy, Louise D. Acton Building, 31 George Street, Queen's University, Kingston, ON, K7L 3N6, Canada. Email: christiana.okyere@queensu.ca 